\title{
Searching for alternative worldviews - how need thwarting, group characteristics and the social environment determine ideological extremism.
}

\author{
Veronika Müller*
}

\begin{abstract}
Using data from the Profiles of Individual Radicalization in the United States (PIRUS) database $(\mathrm{N}=884)$, this study shows that lack of identification with the American belief and social value system, and group grievance, are both significant predictors in explaining why individuals reach out to ideological, extremist groups, prior of showing violent behavior. This means that low levels of identification with socially shared norms, values, narratives and beliefs and the attachment to a group that is believed to be under threat, increases the chance that individuals question the established systems and search for alternative, even extremist, worldviews.
\end{abstract}

JEL Classifications: D74, D91

Keywords: Ideological Extremism, Human Needs, Collective Grievance, Extremist Groups

* Corresponding author: Veronika Müller, Department of Economics, Paderborn University, Warburger Str. 100, 33098 Paderborn, Germany, e-mail: muellerv@ campus.uni-paderborn.de, Tel: +49 5251 602115 


\section{Introduction}

In the last decades, scholars have put much effort in analyzing and explaining why some individuals join violent groups and are willing to accept a high level of personal risk to advance those groups' goals. Theoretical and empirical contributions offer hereby micro-level, psychological (e.g., Jasko et al., 2017; Hogg \& Adelmann, 2013; Kay \& Eibach, 2013; Fischer et al., 2010; Leary et al., 2006; Silke, 2008; Gill et al., 2014; Gruenewald et al., 2013) and macro-level, socio-political explanations (e.g., Sageman, 2004; Mousseau, 2011; Piazza, 2011; Ostby, 2013; Pinstrup-Andersen \& Shimokowa, 2008). Conventional rational-choice theories in economics often argue that individuals join radical groups as the product of economic calculations. In other words, individuals are mostly driven by economic motives, either for "greed", "loot", or gains from victory of a conflict or just from membership itself (Cramer, 2002). Berman \& Laitin (2008) state that extremist organizations like Hamas, Hezbollah, the Taliban, or the Egyptian and Palestinian Muslim Brotherhood provide their members and member's families exceptional goods and social services to bind them to their organization. This club model was first emphasized by Iannaccone (1992), who argued that religious organizations, in particular, offer excludable goods and services to their members in exchange for their loyalty and norm abidance. Their attempt is to limit members' choices and resources, and hence, to bind them strictly to their organization, its goals, norms, and worldviews. In so doing, group members have little or no opportunities outside the group and are isolated from the outside world. They are obliged to sacrifice and show their strict commitment, while having limited contact to outgroups and the external social environment. Both studies (Berman \& Laitin, 2008; Iannaccone, 1992) argue that those who have poor market opportunities, poor education, and low wages, in particular, are more willing to join radical groups or organizations and abide by their behavioral norms, beliefs, and rules. 
Following this view, macro-level, socio-political analysis emphasizes that poverty, deprivation, and limit of choice drive individuals to join radical groups. The opportunity cost of insurgency, especially for young males who are living under precarious living conditions with few or any prospective alternatives, is hence clearly low (Hirschleifer, 1994). But opposite studies show that the majority of extremists do not have a severe socio-economic background, poor education and are not likely to live under extreme poverty (Krueger \& Maleckova, 2003). This led psychologists and sociologists turn to micro-level, psychological factors to explain why individuals join and actively engage in extremist groups (Moskalenko \& McCauley, 2011). Traditional psychological literature examines hereby the idea that individuals join extremist groups or organizations not for calculated reasons but for psychological. Factors such as emotions, group belongingness, grievance about felt injustice, or self-esteem are argued to be more important to explain violent mobilization (Gurr, 1970; Muller \& Seligson, 1987; Basedau \& Lay, 2009). Psychoanalysis assumed for a very long time that psychological drives and hidden emotions, derived from subconsciousness, have a strong impact on individuals' willingness to resort to extremism (Post, 1984, 2007). Others have even promoted the view that radicalization is symptomatic of psychopathology (Shaw, 1986). Antisocial, narcissistic, or borderline personalities have been thus linked to enhanced tendency to radicalization and extremism. The theoretical approach behind argues that individuals who experienced trauma, either as a child or adult, tend to develop an "injured self". This damaged self, and inconsistent self-concept, prevent individuals from integrating the good and bad parts of their self and to understand and accept the strength and weaknesses of one's personality. Instead, they idealize their good self and projects their hated weakness onto others (e.g., adoption of racist beliefs that denigrate a group of individuals). Unable to reconcile their self-deficiencies, individuals with such personalities join radical groups in order to promote their "powerful self" and attack external enemies to diminish the uncertain self (Post, 1984). In contrast to this theoretical approach, clinical interviews with imprisoned terrorists reveal no evidence of psychopathology. 
Clinical examinations of right-wing extremists of the Baader-Meinhof group in Germany (Rasch, 1979) and left-wing extremists in Italy reveals that all individuals showed no mental disorders or other indication of psychopathology (Ferracuti \& Bruno, 1985). Similar results have been obtained in the U.S. (Knutson, 1979), and in Algeria, where interviewed members of the National Liberation Front (FLN) have been found to be mentally stable (Crenshaw, 1981). According to these results, individuals who join extremist groups and eventually participate in rebellion or terrorism have been found to neither display psychopathological symptoms nor particular personality traits that induce a "terrorist mindset" (Shaw, 1986).

Instead, psychological studies show that, not individual dispositions ${ }^{1}$ or mental illness drive individuals to extremism, but failed social relationships, lack of attachment, and loss of meaning in life. An interdisciplinary study with 250 West German extremists, of which 227 were leftwing-, and 23 right-wing extremists, found that the majority came from fragmented families and experienced loss of significance in life (no achievements). The authors argue that joining an extremist group is seen as the last opportunity to restore self-significance and find stability in life (Jäger et al., 1981). A recent study (Jasko et al., 2017) found similar results for 1496 individuals who have committed ideologically motivated crimes in the United States. Twelve percent of the entire sample failed to achieve educational or occupational success, however, a strong majority of the sample (65 percent) belonged to the middle class. Nearly half of the individuals have failed to achieve goals in life, or never strived for achieving them. Twentytwo percent experienced conflict in romantic relationships, while 29 percent indicated to have

\footnotetext{
${ }^{1}$ Especially in the 1950s and 60s, psychologists, like Adorno (1950), attempted to identify personality types that are receptive to extreme worldviews and behavior (fascism, authoritarianism) by relying on Freudian methodology. Such a personality was characterized as action-driven, aggressive, and obedient to authority, with preferences for conventionality, categorizations, and punishment of deviants. Rokeach (1960) extended the theory by psychological dogmatism to measure close-mindedness; and in the 1970s some researchers analyzed distinctive dispositional factors to explain the rise of protest movements and rebellion (Condor \& Brown, 1988). All these approaches assumed that dysfunctional personalities could explain individual's willingness to join extremist groups, adopt radical beliefs and participate in rebellion.
} 
lost their social standing and 36 percent were rejected from a social group or organization. The majority of individuals were relatively young (M=32.24 years) and male (90 percent). Only 10 percent had an immigration background, 63 percent finished high school and only 17 percent had a criminal past. The authors argue that despite individual characteristics, violent extremism can be explained by a set of conditions that generate a sense of personal insignificance, mainly induced by economic failure and social detachment. "At the bivariate level when individuals experienced failure at work, when they were rejected in social relationships, or when they were victims of abuse, they were more likely to resort to violence to pursue their ideological goals. These results are consistent with the quest for significance theory (Kruglanski et al., 2014), according to which variables that decrease the sense of personal significance should produce similar effects - that is, they should be related to a higher probability of using extreme (in this case violent) means" (Jasko et al., 2017, p.827). Engaging in violent extremism can be thus perceived as a mean to resolve self-insignificance, because violent acts are more viable and visible, and thus may signal greater commitment, power, and certainty about the intentions of the perpetrators. Further studies by the same authors (Kruglanski et al., 2018; Jasko et al., 2019) confirm that the search for self-significance and meaning in life, as well as social recognition can, at least partly, explain ideological extremism.

Although these psychological studies emphasize the role of violence-justifying ideological narratives, none of them consider beliefs as the driving force of radicalization. Economic and political discourse, indeed, conceive radicalization as the process of embracing radical beliefs, and hence, perceive ideology as a potential source of violent extremism. However, some studies link ideologies more to the idea of "brainwash", propaganda, and indoctrination, allocating individuals a rather passive role of ideological influence (Crone, 2016). On the opposite, Inannaconne (1992), for example, argues that any ideology, or religion, in particular, is an "object of choice: demanders choose what religion (if any) they will accept and how extensively they will participate in it" (p. 272). Accordingly, scholars have started to observe religion, or 
any other ideology, and the membership in a particular group as an instance of rational choice rather than as an exception to it. Individuals are not merely passive receivers of beliefs or ideas they have been exposed to, but rather embrace beliefs and ideologies that resonate with their preferences, needs and interests (Jost, 2017).

Consistent with this view, recent data on global terrorism and conflict shows that ideologies were the main driver of 75 severe conflicts in 2018 and 69 conflicts in 2019, causing more fatalities than any other conflict item (HIIK, 2018, 2019). A number of significant research articles report that since 2001, more ideologically based terrorist groups have been formed than before (Jones \& Libicki, 2008). Especially religious extremist groups represent the highest number of newly formed groups, followed by left-wing extremist and (ethnic) nationalist groups. However, the average number of newly formed religious extremist groups more than tripled in the last years, being highly representative especially in low- and middle-income countries with a partly free democratic or autocratic political system (Gaibulloev and Sandler, 2019). But also, in developed, Western societies, a high number of individuals moved to conflict prone zones and actively participated in armed, Islamic struggle. In 2015, 5000 individuals from Western countries have been reported to travel to Syria or Iraq to support the Islamic State (Soufan Group, 2015). To explain their motives, several analyses postulate that individuals are not driven by economic or political factors, but rather by the ideology itself and psychological reasons, such as lack of meaning and attachment, feelings of alienation, isolation and rejection, disorientation, moral vulnerability, or instability (Wiktorowicz, 2005; Benmelech \& Klor, 2016; Loken \& Zelenz, 2017).

\section{Theory of Psychological Human Needs}

These psychological reasons can be "condensed" in the theory of psychological human needs. Individuals have a variety of psychological human needs which can be classified, among others, into three categories - existential, relational, and self-related human needs (Gries \& Muller, 
2020). Existential needs refer to a variety of needs that imply a safety-seeking mechanism. Since individuals are confronted with complex conditions, such as ambiguous information, unpredictable circumstances, unstable socioeconomic and political conditions, and threatening events, they strive to restore a sense of safety, certainty, and control over their environment, in order to make appropriate choices. In this regard, individuals have the need for safety/security (Pyszczynski et al.,1997), order (Brandt \& Reyna, 2010), control (Kay \& Eibach, 2013), ambiguity avoidance (Hsu et al., 2005; Grenier et al., 2005), consistency (Cialdini et al., 1995), and predictability (Pervin, 1963; Berns et al., 2001). These needs encompass the human necessity to secure one's own existence, to have a sense of control, and to live in an ordered, predictable, and consistent environment. To survive and be mentally healthy, human beings also need social connections. This means that individuals have a natural drive to form relationships and to connect with significant others. They aim to maintain a sense of belonging, to share their identity, values, and ideas with significant others, to feel loved and approved by other members of their group. Hence, individuals have relational needs - the need for belongingness (Leary et al., 2006; Baumeister \& Leary, 1995), identification (Hogg, 2000; Verkuyten \& Martinovic, 2012), and social approval (Grasmick \& Green, 1980). However, human beings are not only social beings, but also have distinct personal dispositions, desires, goals, and preferences. Individuals want to make autonomous choices, feel efficacious in their aspirations and decisions, and have a positive self-view. So, beyond needs for survival and sociality, individuals have self-related needs, i.e., the need for self-esteem (Baumeister, 1993), self-determination (Deci \& Ryan, 2012), and self-efficacy (Bandura, 1994; Maddux, 1995).

The satisfaction and actualization of these needs is fundamental for individuals' mental and physical health. Several researchers have thus established a link between violence and need thwarting - the frustration of or lack of opportunities to satisfy these fundamental human needs. Studies on lone wolf terrorism, for example, shows that individuals who actively participated in terrorism and violence were more likely to be isolated, had more relationship troubles and 
experienced social rejection in the past (Gruenewald et al., 2013; Danzell \& Maisonet Montanez, 2016). Thwarted relational needs in form of weak attachments to significant others, isolation, and social disapproval have been regarded as strong predictors of propensity towards violence (Leary et al., 2006). Similar studies provide evidence that experiences of identity and group threat tend to drive aggressive reactions and increase the tendency to resort to violent means (McCauley \& Moskalenko, 2011; Warburton et al., 2003). But also thwarted needs for certainty, self-esteem, and self-efficacy (self-significance) drive the endorsement of radical beliefs and the membership in ideologically motivated extremist groups (Hogg et al., 2010; Hogg \& Adelman, 2013). According to that, the uncertainty-reduction theory postulates that individuals strive to identify with a well-defined, consistent, and strong group because it provides certainty and orientation, by elevating one's own self-esteem. Empirical studies provide evidence that individuals with strong self-doubts and self-uncertainty tend to identify more strongly with their ingroup and value their ingroup more than individuals with a certain self (Hogg, 2000). Similar results have been found in studies with Turkish and Russian immigrants in different European countries, which reveal that thwarted needs, such as the need to belong, identification, certainty, or self-esteem, tend to enhance their tendency to identify more with their heritage, adopt a radical worldview and decrease their willingness to adjust to society (Verkuyten \& Martinovic, 2012; Simon et al., 2013; Spiegler et al., 2019; Verkuyten \& Reijerse, 2008; Berry, 1997; Robinson, 2009).

Taken together, these studies indicate that depriving individuals from serving their needs can result in antisocial, deviant, or even violent behavior. Belief systems and group membership, irrespective of type and setting, can provide viable means to reduce need-thwarting and generate stability and consistency in life. Belonging to and identifying with a particular ideological group serves individuals' relational needs to the extent that they experience loyalty, trust, and moral support, which emphasizes their feeling of being heard, accepted, and understood. Such groups do not always have to imply extremist features, yet if individuals are denied the opportunity to 
actualize their needs, are cognitively and morally vulnerable, experience identity confusion or group threat, and do not know where to belong, radicalization can occur.

\section{The Present Study}

This study argues that if individuals are denied access to resources or opportunities to satisfy their particular psychological needs, they will be more likely to adopt radical beliefs and seek out membership in extremist groups, in order to find need reconciliation. In this study the role of ideologies is highly emphasized, in particular, their role in reconciling human needs. Need reconciliation, in this context, mean to explain an internal psychological process of conflict resolution. In other words, individuals search for viable ways or options to reduce the inner tension (the inner conflict) that arises due to thwarted or threatened needs (Max-Neef, 1992). Belief systems, or ideologies in political terms, play an important role here because they have the ability to reconcile human needs. They consist of an interrelated set of norms, values and attitudes that is shared within an identifiable group and imply palliative and ontological functions (Jost \& Hunyady, 2003). The ontological function offers individuals alternative interpretations and explanations of reality, i.e., narratives that enable individuals to understand and link the past, present, and potential future, and integrate this coherent story with their own life (and existence). This integration and understanding of life events, circumstances, and the own role in a given environment, create coherent patterns of reality that generate a sense of meaning ${ }^{2}$ in individuals' lives. Having consistent, predictable narratives and beliefs that explain and bring the complex world into order and a sense of control, serve individuals' existential needs. The meaning-making mental system helps individuals to process environmental stimuli (e.g., information), to make decisions, and to understand oneself and the social environment (the structure of society, the different groups in it, own social role and standing). However,

\footnotetext{
${ }^{2}$ Meaning, from a basic point of view, can be understood as a shared mental representation of reality. Meaning emerges from organizing environmental stimuli (e.g., information) into consistent and reliable patterns, which enable individuals to survive and make appropriate decisions (MacKenzie \& Baumeister, 2014).
} 
individuals do not create their own ideologies but select those that society, or particular groups, have to offer (MacKenzie \& Baumeister, 2014). Sharing an ideology, and its ideas, values, and norms with a group or society, offer a basis for identification and social identity formation. Having the same beliefs, goals, attitudes, and sharing a group identity does not only provide consistency and meaning in life, but also serves relational and self-related human needs. It generates a sense of belonging, loyalty, and trust, by emphasizing the significance of each individual in the group. Belonging to a powerful group, sharing its identity, and following its rules and goals, elevates one's self-esteem and generates a sense of autonomy and efficacy in life (Jost, 2017; Knight, 2006).

Taken all together, it becomes clear that ideologies seem to be a "natural" part of human psychological functioning and thus appear to provide a viable way to address and satisfy psychological human needs. This means that individuals choose an ideology that resonates with their needs, desires, and preferences. Joining a group, even if extremist in nature, adhering to their rules, beliefs, and norms, and actively participating in it can be thus explained in terms of its (perceived) psychological benefits (Iannaconne, 1998). While a vast amount of literature has already examined the process of radicalization, this study goes a step back and considers the factors that motivate individuals to actively reach out to ideologically motivated, extremist groups, before becoming violent and radical. By using an open-source sample of 2200 homegrown extremists in the United States (PIRUS), the present research considers only cases $(\mathrm{N}=884)$ in which individuals decided to connect to ideologically motivated, extremist groups, prior to showing radical behavior. In this regard, trajectories of individual's beliefs or behaviors are not considered (as in case of radicalization), but rather the motives and conditions that drive individuals to actively reach out to extremist groups. In other words, this study examines a sample of individuals who made the choice to reach out to ideological, extremist groups before showing any radical, illegal, and violent behaviors. Identifying the factors that drive individuals to make this decision helps to better understand each step of the radicalization process, and 
hence, to implement political and social measures to prevent, or decrease the tendency of such choices.

The motives and conditions are synthesized here into three main predictors: i) fundamental (psychological) human needs; ii) social environment; and iii) extremist group's characteristics. Since the data is not based on experiments or surveys, but on publicly available sources, this study uses a variety of proxy variables - such as socio-economic background, traumatic experiences, unstructured lifestyle, social rejection etc. - to measure relational, existential, and self-related human needs. Considering the theoretical and empirical findings, which emphasize the link between human needs and extremism, the discussion leads to the following hypothesis:

H1: Holding all else constant: Depriving individuals from resources or opportunities to serve their particular set of relational, existential, and self-related human needs, enhances the chances that individuals will actively reach out to ideologically motivated, extremist groups.

As suggested before, ideologies provide a viable reconciliation option to address and satisfy individuals' psychological human needs. Individuals will thus choose an ideology, and a particular group, that resonates with their needs, desires, and preferences. Empirical evidence shows that groups, which are particularly motivated by religion or ethnic nationalism, are more lethal and successful in their operations, regardless of their size or network (Asal \& Rethemeyer, 2008). Beyond ideology, particular group characteristics also determine individual's choice. Empirical studies suggest that individuals will join groups that are perceived to be powerful, impactful, strong, and persistent (Hogg \& Adelmann, 2013). These group characteristics are more effective in reducing uncertainty, lack of meaning and selfinsignificance, in particular, because they provide distinctive, simple, and clear narratives and a closed, undisputable worldview. They imply a hierarchical organizational structure, strict behavioral norms, and clear role prescriptions, which give orientation and a sense of meaning in life (Hogg et al., 2010; McGregor, Nash and Prentice, 2013). Authoritarian, homogeneous, and action-driven groups, that appear to be impactful, strong, and popular, and that propagate 
dogmatic ideologies, attract individuals that search for alternative options to serve their set of relational, existential, and self-related needs. These arguments lead to a variety of hypotheses:

H2: The larger the membership size of ideologically motivated, extremist groups, the higher the chances that individuals will actively reach out to them.

H3: The older, and hence more established, the ideologically motivated, extremist groups, the higher the chances that individuals will actively reach out to them.

H4: The deadlier, and thus more impactful, the ideologically motivated, extremist groups, the higher the chances that individuals will actively reach out to them.

H5: The use of traditional media to increase the group's visibility and opportunity to disseminate their beliefs and goals, increases the chances that individuals will actively reach out to them.

H6: Groups that display either a radical right or Islamic ideology increases the chances that individuals will actively reach out to them.

Following the discussion of social psychologists, an important factor that determine the direction of extreme commitment to a particular ideology or group is the social environment in which individuals form their identities (Simon \& Hamilton, 1994; Lüders et al., 2016). The selfcategorization theory (Turner et al., 1987) and social identity theory (Tajfel \& Turner, 1979) argues that affiliation and group belongingness represent crucial parts of the social self. They form individuals' awareness that they belong to a particular group, culture, or social category, and hence, influence their perception of oneself and others (Stets \& Burke, 2000). However, beyond positive effects of attachment, a particular social context can influence the adoption of radical beliefs and the intention to participate in radical networks. Belonging to and identifying with a particular social group, like a clique, family, or religious association, can influence individual's perception of the world and change their attitude towards violence. Empirical studies show that the norms, values, and attitudes that are hold and accepted within a group have a significant impact on individual's behavior, perception, and preferences. If for example, violent acts are validated within a group or society, such acts are regarded as normative and are 
hence not questioned by its members (Webber et al., 2013). Individual’s preferences for fairness and justice are also shaped by their social context, that is, they depend on who they feel they are, on external feedback from others, and on social interactions (Akerlof \& Kranton, 2010). Considering this discussion, this study emphasizes the role of individuals's social context and expects that the willingness of individuals to actively connect to ideologically motivated, extremist groups will be determined by their level of embeddedness within a particular social group (family, clique, radical friends), and their ideological background.

H7: The embeddedness of individuals in a clique, or attachment to already radicalized friends, can enhance the chances that individuals will actively reach out to ideologically motivated, extremist groups.

H8: An ideologically shaped familial background increases the chances that individuals will actively reach out to ideologically motivated, extremist groups.

To my knowledge, there are no prior studies that directly tested the impact of thwarted human needs, the social context, as well as particular properties of extremist groups that influence individual's willingness to actively connect to these groups. In investigating the hypotheses, I also include some control variables which will be presented in the following.

\section{Data and Methodology}

Data for this study was derived from two main sources. The primary source was the Profiles of Individual Radicalization in the United States (PIRUS) dataset - a deidentified, cross-sectional and quantitative dataset of over 2200 individuals in the United States. The second source was the Reputation of Terror Groups dataset (RGT), which includes data on 443 terrorist groups operating across 31 years. The PIRUS dataset has been collected, coded, and maintained by the START Center (National Consortium for the Study of Terrorism and Responses to Terrorism) at the University of Maryland. It is based on publicly available sources of information on the backgrounds, attributes, activities and radicalization processes of violent and non-violent extremists who adopted a far right, far left or radical Islamist ideology. RGT data has been first 
collected and used by Efe Tokdemir and Seden Akcinaroglu (2016), who used and combined data from several well-known databases, such as the Global Terrorism Database (GTD), PRIO, RAND or BAAD. The data cover information on various characteristics of extremist groups, such as group size, number of attacks and fatalities, recruitment measures, funding, media presence and many more, to measure the popularity of these groups. Based on the hypotheses and the two datasets, this study includes only 884 individuals, who actively reached out to ideologically motivated, extremist groups, prior to showing violent behavior. In the following, I first present descriptive statistics to provide a broad overview of the data and a bivariate analysis, computed on the original dataset. Given the large number of missing variables, the multiple imputation by chained equations (MICE) method is applied, followed by a logistic regression with the imputed values to determine which of the predictors were significantly related to individual's choice to reach out to ideological, extremist groups.

\section{Dependent and Independent Variables}

The dependent variable Actively Connect describes an individual's attempt to actively reach out to an extremist group to become a member, before showing radicalizing behavior. To explain and understand this active choice to connect $(\mathrm{No}=0$, Yes $=1)$, I include three main predictors: (i) fundamental (psychological) human needs, (ii) social environment, (iii) extremist group characteristics, and a set of control variables.

(i) Fundamental (psychological) human needs

In this study I included proxy variables to measure the thwarting/deprivation of individuals' fundamental human needs. The needs are classified into three main categories: existential needs, relational needs, and self-related needs. To measure the first need category - existential human needs - five main variables have been used: Itinerant, a dichotomous variable, describes individual's state of constant movement without any stable living space. I assume that residing more than in one location in the United States and constantly moving around can be interpreted 
as lack of stability and certainty in life, and hence as a thwarted need for stability/certainty. To measure the need for existential/economic safety, I included the variable Social Stratum Adulthood. Experiencing an existential threat, low socio-economic conditions and living close to the poverty line deprive individuals from resources to serve their need for existential safety. The next two variables, Unstructured Time and Trauma, measure the thwarted need for order/structure and consistency. The need for order/structure is thwarted when individuals experience disorder, lack of structure and meaning in their lives; and the need for consistency is thwarted in terms of traumatic experiences and events in life (such as threatened death or serious injury, or a threat to the physical integrity of others), which create an inconsistent perception of oneself and the environment. ${ }^{3}$ Another important variable is Group Grievance, which measures the thwarted need for existential safety of a group, to which the subject belongs to or identifies with. Identifying or feeling attached to a group that is believed to be under threat (real or imagined), or has been subject to injustice, can influence individual's perception of grievance. This means, that individuals who may have a good social standing, but feel that their social group is under threat or is treated unfairly, can feel compelled to retaliate injustices committed against social others (McCauley \& Moskalenko, 2011).

To measure relational human needs, three variables have been used: Angry US and Kicked Out, both dichotomous variables, describe the level of identification and belonging to the US society. The first dummy measures whether the subject have negative feelings towards the society, or do not accept the American social value system, which may suggest a thwarted need for

\footnotetext{
${ }^{3}$ Read more about trauma and consistency in Janoff-Bulman's book "Shattered Assumptions" (1992). The author proposes that all human beings strive to perceive their social environment as consistent, reliable, and just. But violent assaults, abuse, natural disasters, or terror attacks, all which threaten our physical and psychological existence, "shatter" these assumptions of a reliable and consistent world. The self is perceived as helpless and fragile, the environment as dangerous and unreliable. After experiencing traumatic events, individuals tend to engage in (mostly unconscious) defensive strategies to decrease the sense of threat and uncertainty, and to regain "mental equilibrium". Such strategies can vary between positive and negative accommodations, which may also induce violence and aggression (Joseph \& Linley, 2008).
} 
identification. The second dummy indicates whether the subject has ever experienced ostracism or marginalization, which may suggest a thwarted need for belongingness. The third variable, Standing, measures whether the subject has experienced social disapproval from a group or society, such as lost respect of close friends or family, public embarrassment, or social exclusion, which may suggest a thwarted need for social approval. The last need category self-related human needs - is measured in terms of three variables: Work History describes whether the subject was regularly employed or has experienced rather unstable or long-term unemployment, which can be indicative of a thwarted need for self-efficacy. Employment considers individual's status of employment, which may suggest a thwarted need for selfdetermination, while Aspirations describes whether the individual has failed to achieve his aspirations in life, which can have a negative impact on his self-esteem (thwarted need for selfesteem).

(ii) Social environment

To measure individual's exposure to an ideologically influenced, radical social environment, I included three variables, which indicate to which extent the membership of a clique, a radical friend and the ideology of the family have a significant impact on individual's choice. The variables Clique and Radical Friend describe whether the subject was part of an exclusive and closed group of people, and whether a close friend of the subject was involved in radical activities. The variable Family Ideology considers if the individual is embedded in an ideologically influenced environment, in particular, the ideology of the individual's immediate family. The recoded dummy aims to explore whether the individual has been exposed to an ideology, without being interested in the particular form of the ideology. The variable Radical Friend is coded on a 4-point scale, indicating a higher level of radicalization with increasing number. 
(iii) Extremist Group Characteristics

Considering particular properties of extremist groups, I used five variables to measure the appeal of these groups: Orgsize describes the size of the organization or group, which is coded on a 4-point scale so that 10,000 members and over was coded highest (4), followed by 1,000 9,999 members (3), 100-999 members (2) and lowest number if 10-99 members (1). The next numeric variable Persistence measures the age of a group or organization, while Impact covers the accumulated number of fatalities in a given year. All three variables display the number that is present at the date at which the individual's activity first came to public attention (e.g., first visible activity in year 2017 so that organizational size, number of fatalities and age is adjusted to 2017). Further variables describe the present ideology in the group (Ideology), which varies between far right, far left, and radical Islamic ideology; and traditional media presence (Media), which displays whether an extremist group has daily broadcasting TV or/and a radio channel to spread their ideas and beliefs.

Control variables: Further I included a variety of control variables that may explain individual's choice to actively reach out to an extremist group, such as age, gender, marital status, education, and personal beliefs.

\section{Results}

\section{Descriptive Statistics}

The descriptive statistics for the given dataset (Table 1), covering 884 individuals, provide an overview of the number of observations, missing values, the coding scheme, and the distribution for each of the variables. Considering the dependent variable, it can be seen that $37 \%$ out of 884 individuals actively reached out to extremist groups. So, in this study I'm particularly interested in these $37 \%$ of individuals who made the choice to connect to ideologically motivated extremist groups. Looking at the results for each need category, nearly $43 \%$ of the sample spent an extended period of time residing in more than one location in the United States. 
As assumed before, constant movement and unstable living conditions may indicate lack of stability and orientation in life (no consistent/stable place), and hence a thwarted need for certainty/stability. The majority of the sample $(63 \%)$ belonged to the upper or lower middleclass, which means that only $25 \%$ of individuals suffered from existential threat (live close to poverty line). However, $35 \%$ were personally attached to or had direct experience with a group that was believed to be under threat or had been subject to injustice (group grievance). Overall, most of the individuals had an ordered life structure and were not exposed to traumatic and threatening events in the past $(64 \%)$.

With regard to relational needs, a strong majority of the sample (78\%) neither experienced ostracism or discrimination, nor a loss of social standing (social approval). However, nearly $65 \%$ experienced belief vulnerability, meaning that the majority questioned the validity of the American social value/belief system, and hence could not identify with the cultural, political, or social norms, beliefs, and values of the country. Considering self-related needs, $13 \%$ of the sample were long-term unemployed, and thus had low opportunities to be efficacious in their decisions and actions (thwarted need for self-efficacy), while nearly $78 \%$ failed to achieve educational or career aspirations or even showed no clear goals and ambitions in life. The results regarding the social environment shows that almost half of the sample were embedded into a group or clique, and nearly $44 \%$ of individuals had a close friend who engaged in extremist violence. Almost $40 \%$ of the sample had an ideologically influenced familial background. As concerns particular properties of extremist groups, individuals were attracted to groups (77\%) that had a large membership size (1000-9999), were nine or ten years in existence, and had a large impact on society (high number of fatalities). Further, individuals were mostly drawn to groups, which displayed mainly a radical Islamic (31,7\%) or Far Right (39\%) ideology, and which used traditional media, such as broadcasting TV or radio channels, to disseminate their ideological beliefs $(70 \%)$. 
Looking finally at control variables, most of the individuals were male (90\%), single or divorced, and relatively young ( $M=33$ years), whereby a larger part of individuals were adolescents or young adults in their twenties. Only $16 \%$ had no high school diploma, but nearly $65 \%$ shared many of the beliefs of a particular radical ideology or felt even a deep commitment to radical ideological beliefs.

Table 1: Descriptive Statistics, Coding, Frequency and Missing Values

\begin{tabular}{|c|c|c|c|c|}
\hline Variable & $\mathrm{N}$ & Coding & Frequency & Missing values $\%$ \\
\hline \multirow[t]{2}{*}{ Actively Connect } & 884 & $\mathrm{No}=0$ & $63 \%$ & $0 \%$ \\
\hline & & Yes $=1$ & $37 \%$ & \\
\hline \multicolumn{5}{|l|}{ Group Characteristics } \\
\hline \multirow[t]{4}{*}{ Orgsize } & 309 & $10-99=1$ & $15,53 \%$ & $65,1 \%$ \\
\hline & & $100-999=2$ & $6,15 \%$ & \\
\hline & & $1000-9999=3$ & $77,02 \%$ & \\
\hline & & $>10000=4$ & $1,29 \%$ & \\
\hline Impactnkill & 314 & numerical & $M(1260,6)$ & $64,5 \%$ \\
\hline Persistenceyears & 316 & numerical & $\mathrm{M}(22,27)$ & $64,25 \%$ \\
\hline \multirow[t]{2}{*}{ Media } & 314 & $\mathrm{No}=0$ & $30,67 \%$ & $64,25 \%$ \\
\hline & & Yes $=1$ & $69,43 \%$ & \\
\hline \multirow{2}{*}{ Ideology Islamist } & 884 & No $=0$ & $68,33 \%$ & $0 \%$ \\
\hline & & Yes $=1$ & $31,67 \%$ & \\
\hline \multirow[t]{2}{*}{ Ideology Far-Right } & 884 & $\mathrm{No}=0$ & $60,75 \%$ & $0 \%$ \\
\hline & & Yes $=1$ & $39,25 \%$ & \\
\hline \multirow[t]{2}{*}{ Ideology Far-Left } & 884 & No $=0$ & $84,84 \%$ & $0 \%$ \\
\hline & & Yes $=1$ & $15,16 \%$ & \\
\hline \multicolumn{5}{|l|}{ Social Environment } \\
\hline \multirow[t]{2}{*}{ Clique } & 764 & $\mathrm{No}=0$ & $55,50 \%$ & $13,6 \%$ \\
\hline & & Yes $=1$ & $44,50 \%$ & \\
\hline \multirow[t]{3}{*}{ Radical Friend } & 578 & $\mathrm{No}=0$ & $21,63 \%$ & $34,6 \%$ \\
\hline & & Yes, but legal = 1 & $12,28 \%$ & \\
\hline & & Yes, illegal, nonviolent $=2$ & $22,15 \%$ & \\
\hline \multirow[t]{2}{*}{ Family Ideology } & 298 & No $=0$ & $62,75 \%$ & $66,3 \%$ \\
\hline & & Yes $=1$ & $37,25 \%$ & \\
\hline \multicolumn{5}{|l|}{ Existential Needs } \\
\hline \multirow[t]{2}{*}{ Itinerant } & 628 & $\mathrm{No}=0$ & $57,17 \%$ & $28,9 \%$ \\
\hline & & Yes $=1$ & $42,83 \%$ & \\
\hline \multirow[t]{2}{*}{ Unstructured Time } & 486 & No $=0$ & $63,17 \%$ & $45 \%$ \\
\hline & & Yes $=1$ & $36,83 \%$ & \\
\hline \multirow[t]{3}{*}{ Social Stratum } & 543 & High $=0$ & $11,23 \%$ & $38,6 \%$ \\
\hline & & Middle $=1$ & $63,35 \%$ & \\
\hline & & Low $=2$ & $25,41 \%$ & \\
\hline \multirow[t]{3}{*}{ Trauma } & 336 & $\mathrm{No}=0$ & $64,29 \%$ & $62 \%$ \\
\hline & & Yes, but long ago $=1$ & $27,08 \%$ & \\
\hline & & Yes, radical, violent $=3$ & $43,94 \%$ & \\
\hline \multirow[t]{3}{*}{ Group Grievance } & 587 & No $=0$ & $33,39 \%$ & $33,6 \%$ \\
\hline & & Yes, but not personal $=1$ & $31,18 \%$ & \\
\hline & & Yes, personal, direct $=2$ & $35,43 \%$ & \\
\hline \multicolumn{5}{|l|}{ Relational Needs } \\
\hline \multirow[t]{2}{*}{ Kicked Out } & 323 & $\mathrm{No}=0$ & $78,33 \%$ & $63,5 \%$ \\
\hline & & Yes $=1$ & $21,67 \%$ & \\
\hline Angry US & 627 & No $=0$ & $35,25 \%$ & $29,1 \%$ \\
\hline
\end{tabular}




\begin{tabular}{|c|c|c|c|c|}
\hline & & Yes $=1$ & $64,75 \%$ & \\
\hline \multirow[t]{3}{*}{ Loss Standing } & 323 & $\mathrm{No}=0$ & $78,95 \%$ & $63,5 \%$ \\
\hline & & Yes, but long ago $=1$ & $12,69 \%$ & \\
\hline & & Yes, recently $=2$ & $8,36 \%$ & \\
\hline \multicolumn{5}{|l|}{ Self-related Needs } \\
\hline \multirow[t]{2}{*}{ Employment } & 535 & Employed $/$ self $/$ student $=0$ & $79,25 \%$ & $39,5 \%$ \\
\hline & & Unemployed $=1$ & $20,75 \%$ & \\
\hline \multirow[t]{3}{*}{ Work History } & 442 & Regularly employed $=0$ & $57,47 \%$ & $50 \%$ \\
\hline & & Underemployed= 1 & $29,64 \%$ & \\
\hline & & Long-term unemployed $=2$ & $12,90 \%$ & \\
\hline \multirow[t]{3}{*}{ Aspirations } & 227 & Yes, achieved $=0$ & $22,03 \%$ & $74,3 \%$ \\
\hline & & Failed to achieve $=1$ & $37,44 \%$ & \\
\hline & & No aspirations $=2$ & $40,53 \%$ & \\
\hline \multicolumn{5}{|l|}{ Control Variables } \\
\hline \multirow[t]{3}{*}{ Personal beliefs } & 817 & No radical $=0$ & $1,22 \%$ & $7,6 \%$ \\
\hline & & $\begin{array}{l}\text { Knowledge about radical } \\
\text { ideology }=1\end{array}$ & $34,52 \%$ & \\
\hline & & Radical beliefs $=2$ & $64,26 \%$ & \\
\hline Age & 872 & numerical & $\mathrm{M}(33,18)$ & $1,35 \%$ \\
\hline \multirow[t]{2}{*}{ Marital Status } & 676 & Married $=0$ & $31,66 \%$ & $23,5 \%$ \\
\hline & & Single/divorced=1 & $68,34 \%$ & \\
\hline \multirow[t]{2}{*}{ Gender } & 884 & Female $=0$ & $10,41 \%$ & $0 \%$ \\
\hline & & Male $=1$ & $89,59 \%$ & \\
\hline \multirow[t]{3}{*}{ Education } & 509 & No high school $=0$ & $16,70 \%$ & $42,4 \%$ \\
\hline & & High School=1 & $21,41 \%$ & \\
\hline & & Higher degree $=2$ & $61,89 \%$ & \\
\hline
\end{tabular}

\section{Bivariate Analysis}

The descriptive statistics make clear that a variety of variables can be identified as important explanatory variables, while some may be redundant for the analysis, causing rather errors and misinformation ${ }^{4}$. Including all variables in the subsequent logistic regression, regardless of their significance, can lead to unstable estimates and large standard errors. To identify in the first step potential significant predictors that are worth testing in a logit model, bivariate correlations with the outcome variable are taken into consideration (Table 2). Given that the dependent variable is dichotomous, as well as a variety of predictors, the outcomes for this set of variables in the table are Chi-squared coefficients. For ordinal variables, the outcomes are tau coefficients. To ensure that any potential variables are not dropped from the subsequent analysis, a threshold of $\mathrm{p}<0.1$ has been also applied. The preliminary analysis shows significant

\footnotetext{
${ }^{4}$ Commonly used methods to identify and include (informative) variables in logistic regression models are forward, backward, and stepwise regression (Zellner et al., 2004). However, authors like Cohen (1991) argue that these procedures might lead to misleading conclusions, particularly when the data are categorical. Given that most variables in this dataset are categorical, and are potentially collinear, the method that was further applied was a factor analysis. However, postestimation tests like the Kaiser-Meyer-Ohlkin (0.4) measure of sampling adequacy shows that the data is not suitable to run a factor analysis.
} 
relationships at the bivariate level between some of the predictors and the outcome variable Actively Connect. Looking first at the measures of existential, relational, and self-related human needs, all variables are positively, and some significantly correlated with individual's choice to actively reach out to ideologically motivated, extremist groups. The variable Angry US, which describes a thwarted need for identification correlates positively and highly significantly $(p<$ .001) with the outcome variable. This means, that enhanced belief vulnerability, i.e., low levels of identification with the American social value and belief system, increases the chances that individuals will actively reach out to ideological extremist groups.

Table 2. Bivariate Analysis between Active Connection, Needs, Group Characteristics, Social Environment, and Control Variables

\begin{tabular}{|c|c|}
\hline Variables & Actively Connect \\
\hline \multicolumn{2}{|l|}{ Group Characteristics } \\
\hline Orgsize ${ }^{a}$ & $.1363 * *$ \\
\hline Impact & .073 \\
\hline Persistence & $-.105 *$ \\
\hline Media $^{\mathrm{b}}$ & $11.214 * * *$ \\
\hline Ideology Islamist $^{\mathrm{b}}$ & $111.229 * * *$ \\
\hline Ideology Far-Right $^{\mathrm{b}}$ & $64.650 * * *$ \\
\hline Ideology Far-Left ${ }^{\mathrm{b}}$ & $3.357 *$ \\
\hline \multicolumn{2}{|l|}{ Social Environment } \\
\hline Clique $^{\mathrm{b}}$ & $24.934 * * *$ \\
\hline Radical Friend $^{\mathrm{a}}$ & .009 \\
\hline Family Ideology ${ }^{b}$ & $3.632 *$ \\
\hline \multicolumn{2}{|l|}{ Existential Needs } \\
\hline Itinerant $^{\mathrm{b}}$ & .6986 \\
\hline Social Stratum ${ }^{\mathrm{a}}$ & .0323 \\
\hline Unstructured Time ${ }^{\mathrm{b}}$ & $3.493 *$ \\
\hline Trauma $^{\mathrm{a}}$ & .0807 \\
\hline Group Grievance $^{a}$ & $.201 * * *$ \\
\hline \multicolumn{2}{|l|}{ Relational Needs } \\
\hline Angry US ${ }^{\mathrm{b}}$ & $23.189 * * *$ \\
\hline Loss Standing ${ }^{\mathrm{a}}$ & 2.942 \\
\hline Kicked Out $^{\mathrm{b}}$ & .015 \\
\hline \multicolumn{2}{|l|}{ Self-related Needs } \\
\hline Work History ${ }^{\mathrm{a}}$ & .013 \\
\hline Employment ${ }^{\mathrm{b}}$ & .118 \\
\hline Aspirations $^{\mathrm{a}}$ & .052 \\
\hline \multicolumn{2}{|l|}{ Control Variables } \\
\hline Gender $^{b}$ & .215 \\
\hline Age & $-.202 * * *$ \\
\hline Education $^{\mathrm{a}}$ & -.063 \\
\hline Marital Status ${ }^{b}$ & 1.898 \\
\hline Personal Beliefs ${ }^{\mathrm{a}}$ & $.138 * * *$ \\
\hline
\end{tabular}


The variable Unstructured Time, too, shows a positive and slightly significant $(p=.062)$ relation with the outcome variable, which indicates that a thwarted need for order/structure in life (lack of orientation) drive an individual to actively reach out to ideological extremist groups. Another highly significant variable is Group Grievance. Feeling attached to a group that is perceived to be under threat or that is subject to injustice, i.e., the group's need for existential safety is thwarted, has a positive and highly significant relation with individual's choice to actively reach out to extremist groups.

The next group of variables consider the social environment of individuals. The results suggest that belonging to a particular group - a clique - relates positively and significantly to individual's choice to reach out to an extremist group. Familial ideological background, too, seems to play a positive and slightly significant role $(p=.057)$. Considering the results for group characteristics, the variable Organizational Size has a significant $(p=.014)$ and positive relation with the outcome variable, which suggests that bigger organizations tend to attract more individuals, which also applies for organizations that use traditional media to disseminate their ideologies and goals $(p<.001)$. Especially extremist groups that are motivated by Islamic and Right-Wing ideologies, but to a lesser extent by a Left-Wing ideology, are also more likely to significantly attract more individuals. The relationship between Persistence and the outcome variable is slightly significant and negative, which indicates that rather younger extremist groups seem to attract more individuals. The results for control variables show a negative and highly significant relationship between age and the outcome variable, which indicates that rather younger individuals tend to reach out to extremist groups. A similar significant, but positive link can be observed between personal beliefs and individual's willingness to connect to extremist groups, implying that the more knowledge individuals have about a radical ideology, the more beliefs they share with a radical group, or are even deeply committed to radical beliefs, the more likely they will actively reach out to ideological extremist groups. 
The results of the bivariate analysis make clear that some predictors might be redundant to explain the outcome variable. To avoid high errors and misinformation, and to reduce the number of the predictors, further analyses have been applied to test for multicollinearity, calculate Cronbach's $\alpha$ and standardized $\beta$ coefficients, which enable to compare the relative strength of the predictors within the model. Including the fact that some variables contain a large number of missing data, the following variables have been excluded from subsequent procedures: Itinerant and Trauma are excluded due to very low standardized $\beta$ coefficients and Cronbach's $\alpha$, and the high number of missing values for Trauma (62\%); the variables Kicked Out and Loss Standing correlated $(\tau=.165, \mathrm{p}<.001)$ moderately with each other and were hence summed up by creating a dummy variable Social Exclusion (with 0 if individual experienced no social exclusion and 1 if individual was socially excluded in the past). The variables Work History and Employment also correlate with each other $(\tau=.60, \mathrm{p}<.001)$, and were hence summed up to a dummy variable Achievement (with 0 if individual has achieved something in the past (e.g., study, long-term employment), and 1 if individual has failed to achieve something in the past (e.g., long-term unemployment, not looking for a job)). The variable Aspirations has been excluded because of missing values of over $74 \%$. The variables Clique and Radical Friend correlated moderately with each other $(\tau=.45, \mathrm{p}<.001)$, however, Radical Friend has been rejected from the analysis due to low Cronbach's $\alpha$ and $\beta$ coefficient, which also applies to the variable Family Ideology (more than $66 \%$ missing values). Going further, the variables measuring ideology (Ideology Islamic, Ideology Far-Right, Ideology Far-Left) correlated slightly with each other, and were thus summed up by computing an additive index (Ideology). All other variables measuring group's characteristics contain a large number of missing values (more than 64\%) but were retained in the model $^{5}$.

\footnotetext{
${ }^{5}$ Further, the control variable Gender has been recoded to a dummy variable Male $(0=$ female, $1=$ male $)$, to account for the fact that $90 \%$ of individuals in the sample were male.
} 


\section{Multiple Imputation and Logistic Regression}

Simply eliminating variables with a large number of missing values (such as $73 \%$ missingness of Social Exclusion) is not a recommended method because it would generate loss of data, a reduction of the sample size and a bias in variance estimates (Hertel, 1976; Graham, 2009). To handle the large number of missing data a multivariate imputation by chained equations (MICE) method has been applied (Hawthorne \& Elliot, 2005; Schafer \& Graham, 2002). Rather than deleting missing observations, multiple imputation, in contrast to single imputation, creates multiple datasets to account for the statistical uncertainty in the imputations. In addition, MICE does not assume normal distribution and enables to use a separate conditional distribution for each imputed variable. This means that it can handle variables with varying distributions in the dataset (such as dichotomous, ordinal, and continuous) and specific outcomes, such as a binary outcome variable for a logistic regression. In the process, a series of regression models are run whereby missing values are imputed based on the values of known variables in the dataset. This process is repeated until stable estimates of the distribution of parameters are achieved and a final imputed dataset is formed (Azur et al., 2011). This process is again repeated for a number of cycles until sufficient datasets have been formed, and then analyzed using a statistical method of interest. The number of cycles to be performed and the method of analysis are individually specified by the researcher. Since the data in this paper contain a large number of missing values, I imputed 50 datasets and performed a logistic regression on the pooled datasets in order to use as much information as possible and to provide stable estimates (Graham et al., 2007). Further, I also included the outcome variable (Actively Connect) in the imputation model without imputing values for it, in order to maximize the information for each individual case (Enders, 2010; Graham, 2009). 
Table 3. Logistic Regression for Actively Connect

\begin{tabular}{|c|c|c|c|c|c|c|c|c|}
\hline & \multicolumn{2}{|c|}{$\begin{array}{c}\text { Model 1 } \\
\text { Human Needs }\end{array}$} & \multicolumn{2}{|c|}{$\begin{array}{c}\text { Model 2 } \\
\text { Social Environment }\end{array}$} & \multicolumn{2}{|c|}{$\begin{array}{c}\text { Model 3 } \\
\text { Group parameters }\end{array}$} & \multicolumn{2}{|c|}{$\begin{array}{c}\text { Model } 4 \\
\text { Control Variables }\end{array}$} \\
\hline & $\mathrm{B}(S E)$ & OR & $\mathrm{B}(S E)$ & OR & $\mathrm{B}(S E)$ & OR & $\mathrm{B}(S E)$ & OR \\
\hline \multicolumn{9}{|l|}{ Human Needs } \\
\hline Achievement & $0.142(0.199)$ & 1.15 & $0.118(0.199)$ & 1.125 & $0.151(0.203)$ & 1.16 & $0.078(0.214)$ & 1.08 \\
\hline Unstructured Time & $-0.262(0.23)$ & 0.76 & $-0.187(0.229)$ & 0.829 & $-0.252(0.245)$ & 0.77 & $-0.304(0.272)$ & 0.74 \\
\hline Social Exclusion & $-0.758(0.35)$ & $0.468^{*}$ & $-0.676(0.352)$ & 0.509 & $-0.718(0.380)$ & 0.49 & $-0.734(0.398)$ & 0.45 \\
\hline Angry US & $0.683(0.199)$ & $1.98^{* * *}$ & $0.655(0.199)$ & $1.93^{* * *}$ & $0.637(0.228)$ & $1.89^{\text {** }}$ & $0.641(0.245)$ & $1.90^{* *}$ \\
\hline Group Grievance & $0.415(0.122)$ & $1.51^{* * * *}$ & $0.375(0.124)$ & $1.46^{* *}$ & $0.373(0.158)$ & $1.45^{*}$ & $0.386(0.170)$ & $1.47^{*}$ \\
\hline \multicolumn{9}{|l|}{ Social environment } \\
\hline Clique & & & $0.546(0.163)$ & $1.73^{* * *}$ & $0.400(0.179)$ & $1.49^{*}$ & $0.335(0.179)$ & 1.34 \\
\hline \multicolumn{9}{|l|}{ Group parameters } \\
\hline Ideology & & & & & $0.727(0.348)$ & $2.07^{*}$ & $0.570(0.351)$ & 1.77 \\
\hline Org & & & & & $0.459(0.282)$ & 1.58 & $0.380(0.295)$ & 1.46 \\
\hline Impact & & & & & $-0.000(0.000)$ & 0.99 & $-0.000(0.000)$ & 0.99 \\
\hline Persistence & & & & & $-0.004(0.005)$ & 0.99 & $-0.001(0.006)$ & 0.99 \\
\hline Media & & & & & $-0.228(0.529)$ & 0.75 & $0.062(0.573)$ & 1.06 \\
\hline \multicolumn{9}{|l|}{ Control Variables } \\
\hline Education & & & & & & & $-0.084(0.144)$ & 0.92 \\
\hline Male & & & & & & & $0.149(0.279)$ & 1.16 \\
\hline Personal beliefs & & & & & & & $0.417(0.185)$ & $1.52^{*}$ \\
\hline Age & & & & & & & $-0.028(0.01)$ & $0.97^{* *}$ \\
\hline Marital Status & & & & & & & $0.362(0.226)$ & 1.44 \\
\hline Constant & $-1.27^{* * *}$ & & $-1.493^{* * * *}$ & & $-2.841^{* * * *}$ & & $-2.694^{* * * *}$ & \\
\hline F Statistic & $6.66^{* * *}$ & & $7.05^{* * *}$ & & $3.85^{* * *}$ & & $3.79^{* * *}$ & \\
\hline
\end{tabular}

Note: Standard errors in parenthesis, $\mathrm{n}=848$ for all models, OR $=$ Odds Ratio

${ }^{*} p<0.05,{ }^{* *} p<0.01,{ }^{* * * *} p<0.001$

The results of the logistic regressions with imputed missing values (Table 3) provide mixed support for the stated hypotheses. In Model 1 the vector of psychological human needs (existential, relational, and self-related needs) has been included, condensed into four major variables. In Model 2 variables measuring the social environment has been added, and in Model 3 group characteristics. Model 4 covers all variables relevant for the analysis, also including control variables. Looking at the results it becomes clear that across all four models the variables Angry US and Group Grievance seem to be significant predictors of the outcome variable. This indicates foremost that among individuals, those who experienced a thwarted need for identification were more likely to actively reach out to ideologically motivated extremist groups. This means, that enhanced belief vulnerability, i.e., low levels of identification with the American social value and belief system, increases the chances that individuals reach out to ideological extremist groups. Additionally, among individuals, those 
who identified with a particular group that is perceived to be under threat or that is subject to injustice, were more likely to reach out to extremist groups. In this regard, not the subjectively thwarted need for existential safety plays an important role, but the collectively thwarted need. A direct experience of threat or injustice (real or imagined) in a group increases the chances that individuals actively connect to ideological, extremist groups. This is consistent with the significant variable, clique belongingness, which indicates that being part of a clique increases the chances that individuals will reach out to ideological extremist groups.

These results provide support for Hypothesis 1 and 7, and correspond to the results of the bivariate analysis. Going further and considering group's characteristics, the results show no statistical support for parameters such as organizational size, impact, and persistence, but statistical significance for group's ideology. As mentioned before, individuals were mostly drawn to groups which displayed either a radical Islamist or Far Right ideology, which supports Hypothesis 6. However, including group's characteristics into the analysis decreased both the significance of other variables and the overall impact of the model, which may be explained by the large number of missing values particularly observed for these variables. Finally, in Model 4 control variables have been added to the analysis. The results show that age has a significant and negative relation with the outcome variable, indicating that rather younger individuals were more likely to actively reach out to extremist groups. In addition, personal beliefs have a strong and positive association with the active connection to extremist groups, implying that having a more developed set of radical beliefs (more information, knowledge, and sympathy for a radical ideology) increases the chances that individuals will reach out to extremist groups.

\section{General Discussion}

This research aimed to contribute to a broad discussion led in social science about the motives and factors of individuals to participate in violent, ideological extremism, by analyzing a sample of homegrown extremists in the United States. The focus on a developed and modern Western 
nation allows us to understand the motives of individuals, who neither live under precarious socio-economic and political conditions, nor are deprived of vital resources to survive. In contrast to the constantly held belief that in particular those, who have low market opportunities, poor education, and unstable job conditions, are more willing to join radical groups (e.g., Berman \& Laitin, 2008; Iannaccone, 1992), this paper indicates an opposite direction. The majority of the sample were regularly employed (79\%), well educated (62\%), had a middleclass background (63\%), and neither experienced trauma (64\%), and social rejection (78\%), nor a decrease in social standing (79\%). This means that factors addressing social troubles, lack of achievements or economic failure seem to not play a significant role in explaining why individuals would reach out to extremist groups. This is surprising, because other studies (e.g., Jasko et al., 2017) have emphasized that social detachment and lack of achievements, in particular, increase the chance of violent political extremism. However, these studies considered only cases in which individuals already became violent and committed crimes ranging from illegal protests to planting bombs in public buildings. But this study focused on cases in which individuals reached out to ideological extremist groups prior to exhibiting radical or violent behavior. This enables us to understand the steps before the outbreak of violence, and hence to implement appropriate measures to prevent such decisions in the future.

The results show that the most significant factors that enhance the chances that individuals will actively reach out to ideological extremist groups are, a thwarted need for identification and collective existential safety. Identification plays a significant role in how individuals form their social identity, perceive themselves and their social environment, and how they behave and interact with social others. Identifying with a particular ethnic, social, or cultural group, a nation, or political party enables individuals to form a concept of oneself, that is, one's description, perception, and evaluation of oneself, and the social environment (Abrams \& Hogg, 1990). Identifying with shared norms, values, worldviews, attitudes and symbols of a group or nation regulates feelings of attachment, certainty, and stability. This sense of certainty in turn, 
generates orientation and confidence in how to behave and evaluate, and what to expect from one's social environment (Hogg \& Adelmann, 2013). Especially during adolescence, individuals search for common identifiers, which can be based on ascribed characteristics like nationality, ethnicity, or gender, or on external factors like political convictions or worldviews (Ashmore et al., 2004), in order to find meaning and orientation in life. Empirical studies have shown that social identification increases individual's willingness to contribute to the common good, but also to accept and comply with the social, political, and economic system (Cremer \& van Vugt, 1999). This means that lack of identification with values, norms and beliefs that are shared within a group or nation may reduce individual's willingness to adhere to common norms and values, and thus increases the probability that individuals search for alternative means for identification. The results of this study support these assumptions by revealing that the more individuals could not identify with the American belief-, and value system, the higher the chances that they would search for alternatives in the form of ideological extremism. In the sample, particularly younger individuals, aged between 20 to 30, significantly reached out to ideological extremist groups, which is consistent with the assumption that especially adolescents and young adults question the established social, political, and economic system and search for alternative worldviews to identify with (e.g., Verkuyten, 2018).

Ideologies offer such alternative interpretations and explanations of reality, i.e., narratives that enable individuals to understand the past, present and potential future, and integrate this coherent story with their own life and identity. This integration and understanding of life events, the social environment, and the own role in it, create coherent patterns of reality and generates a sense of meaning in life (Haidt et al., 2009; MacKenzie \& Baumeister, 2014). Sharing beliefs, values, and norms in a group, even if extremist in nature, induces a sense of belonging and identification. Belonging to a powerful group, sharing its identity, and following its rules and goals, elevates one's self-esteem and generates a sense of efficacy in life (e.g., Hogg \& Adelmann, 2013). 
The present findings also highlight the role of group grievance, that is, the collectively thwarted need for existential safety. This means that feeling attached to a particular social group that is believed to be under threat or has been subject to injustice (real or imagined), increases individual's willingness to retaliate. Feelings of group threat, or the collectively thwarted need for existential safety, have significantly stronger effects on the likelihood of ideological extremism than the subjectively thwarted need for existential safety (Social Stratum). This means that individuals' perceptions and experiences of grievance are significantly shaped by the social context in which they are embedded (Akerlof \& Kranton, 2010). Hence, individuals who may have a good social standing, but feel that their social group is under threat or treated unfairly, can feel compelled to retaliate injustices committed against their ingroup (McCauley \& Moskalenko, 2011).

In order to better understand these results, it is important to take the American socio-economic environment and its dominant worldview into consideration. The American social value and belief system has been long dominated by the narrative of the American Dream - a belief that status in society is based on merit, i.e., on individual talents and efforts alone. This strong narrative provided a basis for a shared social identity, offered a vision how the society should look like, and integrated the individual into the social environment. This integration and understanding of circumstances (e.g., understanding of poverty, social inequality), the social environment ("all individuals have the opportunity to succeed on the basis of their own will and effort"), and the own role in it ("I can be whatever I want, I only have to put much effort in it") created a consistent pattern of reality and generated a sense of purpose and meaning in life (Finighan \& Putnam, 2017). However, empirical evidence shows that the U.S. has the highest inequality level of all industrialized countries, with 60 percent of people living in either majority rich or poor neighborhoods (Bartels, 2005; Bischoff \& Reardon, 2014), inducing a highly shrinking middle class. Based on these developments, the narrative of equal opportunity for all, begun to dissolve, especially among the white working class (Page \& Jacobs, 2009). The fading 
shared social identity and vision of the future, paired with enhanced frustration about economic disadvantages of some groups (group grievance), increased doubts about the functioning of the prevailing social, political, and economic system and created an enhanced demand for existential safety, a socially shared identity and orientation. This means that enhanced belief vulnerability, and lack of shared visions about the future that address all individuals in the United States, led to a growing search for alternative worldviews. However, this search can culminate in ideological extremism, leading to extraordinary attacks on democratic norms and social values established in the United States. According to this, and taking the results of this study into consideration, it becomes clear that lack of identification with the socially shared belief system, and feelings of group grievance, increase the chances that individuals will actively search for alternative worldviews to reconcile their psychological human needs. This means that politics should create a "new" basis (in terms of a vision and narrative) for identification that is shared by all diverse groups in the United States, to include, not exclude marginalized groups and individuals.

\section{References}

Abrams, D. E., \& Hogg, M. A. (1990). Social identity theory: Constructive and critical advances. Springer-Verlag Publishing.

Adorno, T.W., Frenkel-Brunswick, E., Levinson, D.J., \& Sanford, R.N. (1950). The authoritarian personality. New York: Harper and Row.

Akerlof, G. A., \& Kranton, R. E. (2010). Identity economics: How our identities shape our work, wages, and well-being. Princeton University Press.

Asal, V., \& Rethemeyer, R. K. (2008). The nature of the beast: Organizational structures and the lethality of terrorist attacks. The Journal of Politics, 70(2), 437-449. 
Ashmore, R. D., Deaux, K., \& McLaughlin-Volpe, T. (2004). An organizing framework for collective identity: articulation and significance of multidimensionality. Psychological bulletin, 130(1), 80 .

Azur, M. J., Stuart, E. A., Frangakis, C., \& Leaf, P. J. (2011). Multiple imputation by chained equations: what is it and how does it work? International Journal of Methods in Psychiatric Research, 20(1), 40-49.

Bandura, A. (1994). Self-efficacy. In V. S. Ramachaudran (Ed.), Encyclopedia of human behavior (Vol. 4, pp. 71-81). New York: Academic Press.

Barrett, R., Berger, J., Ghosh, L., Schoenfeld, D., el Shawesh, M., Skinner, P. M., ... \& Soufan, A. (2015). Foreign fighters: An updated assessment of the flow of foreign fighters into Syria and Iraq. The Soufan Group, 4.

Bartels, L. M. (2005). Homer gets a tax cut: Inequality and public policy in the American mind. Perspectives on Politics, 15-31.

Basedau, M., \& Lay, J. (2009). Resource curse or rentier peace? The ambiguous effects of oil wealth and oil dependence on violent conflict. Journal of Peace Research, 46(6), 757776.

Baumeister R.F. (1993) Understanding the Inner Nature of Low Self-Esteem: Uncertain, Fragile, Protective, and Conflicted. In: Baumeister R.F. (Eds) Self-Esteem. The Plenum Series in Social / Clinical Psychology. Springer, Boston, MA.

Baumeister, R. F., \& Leary, M. R. (1995). The need to belong: desire for interpersonal attachments as a fundamental human motivation. Psychological Bulletin, 117(3), 497529.

Berman, E., \& Laitin, D. D. (2008). Religion, terrorism and public goods: Testing the club model. Journal of Public Economics, 92(10-11), 1942-1967. 
Berns, G. S., McClure, S. M., Pagnoni, G., \& Montague, P. R. (2001). Predictability modulates human brain response to reward. Journal of Neuroscience, 21(8), 2793-2798.

Berry, J. (1997). Immigration, acculturation and adaptation. Applied Psychology: An International Review, 46(1), 5-34.

Bischoff, K., \& Reardon, S. F. (2013). Residential Segregation by Income, 19702009. Prepared for inclusion in Logan (Ed.) The Lost Decade? Social Change in the U.S. after 2000. Russell Sage Foundation

Brandt, M. J., \& Reyna, C. (2010). The role of prejudice and the need for closure in religious fundamentalism. Personality and Social Psychology Bulletin, 36(5), 715-725.

Cialdini, R. B., Trost, M. R., \& Newsom, J. T. (1995). Preference for consistency: The development of a valid measure and the discovery of surprising behavioral implications. Journal of Personality and Social Psychology, 69(2), 318.

Cohen, A. (1991). Dummy variables in stepwise regression. The American Statistician, 45(3), 226-228.

Condor S., Brown R. (1988). Psychological Processes in Intergroup Conflict. In: Stroebe W., Kruglanski A.W., Bar-Tal D., Hewstone M. (Eds.), The Social Psychology of Intergroup Conflict. Springer Series in Social Psychology. Springer, Berlin, Heidelberg.

Cramer, C. (2002). Homo economicus goes to war: methodological individualism, rational choice and the political economy of war. World Development, 30(11), 1845-1864.

Crenshaw, M. (1981). The causes of terrorism. Comparative Politics, 13(4), 379-399.

Crone, M. (2016). Radicalization revisited: violence, politics and the skills of the body. International Affairs, 92(3), 587-604. 
Danzell, O. E., \& Maisonet Montañez, L. M. (2016). Understanding the lone wolf terror phenomena: assessing current profiles. Behavioral Sciences of Terrorism and Political Aggression, 8(2), 135-159.

De Cremer, D., \& Van Vugt, M. (1999). Social identification effects in social dilemmas: A transformation of motives. European Journal of Social Psychology, 29(7), 871-893.

Deci, E. L., \& Ryan, R. M. (2012). Self-determination theory. In P. A. M. Van Lange, A. W. Kruglanski, \& E. T. Higgins (Eds.), Handbook of theories of social psychology (p. 416436). Sage Publications Ltd.

Enders, C. K. (2010). Applied missing data analysis. New York, London: The Guilford Press.

Ferracuti F., \& Bruno F. (1985). A Psychiatric Comparative Analysis of Left and RightWing Terrorism in Italy. In: Pichot P., Berner P., Wolf R., Thau K. (Eds.), Psychiatry. Springer, Boston, MA.

Finighan, R., \& Putnam D. R. (2017). A Country Divided: The Growing Opportunity Gap in America. In Brown, A., Buchholz, D., Davis, D., \& Gonzalez, A. (Eds.), Economic Mobility: Research \& Ideas on Strengthening Families, Communities \& The Economy (pp.139-174). The Federal Reserve Bank

Fischer, P., Haslam, S. A., \& Smith, L. (2010). “If you wrong us, shall we not revenge?” Social identity salience moderates support for retaliation in response to collective threat. Group Dynamics: Theory, Research, and Practice, 14(2), 143.

Gaibulloev, K., \& Sandler, T. (2019). What we have learned about terrorism since 9/11. Journal of Economic Literature, 57(2), 275-328.

Gill, P., Horgan, J., \& Deckert, P. (2014). Bombing alone: Tracing the motivations and antecedent behaviors of lone-actor terrorists. Journal of Forensic Sciences, 59(2), 425435 . 
Graham, J. W. (2009). Missing data analysis: Making it work in the real world. Annual Review of Psychology, 60, 549-576.

Graham, J. W., Olchowski, A. E., \& Gilreath, T. D. (2007). How many imputations are really needed? Some practical clarifications of multiple imputation theory. Prevention Science, 8(3), 206-213.

Grasmick, H. G., \& Green, D. E. (1980). Legal punishment, social disapproval and internalization as inhibitors of illegal behavior. The Journal of Criminal Law \& Criminology, 71(3), 325.

Grenier, S., Barrette, A. M., \& Ladouceur, R. (2005). Intolerance of uncertainty and intolerance of ambiguity: Similarities and differences. Personality and Individual Differences, 39(3), 593-600.

Gries, T., \& Müller, V. (2020). Conflict Economics and Psychological Human Needs. CIE Center for International Economics (No. 135), Paderborn University

Gruenewald, J., Chermak, S., \& Freilich, J. D. (2013). Distinguishing “loner” attacks from other domestic extremist violence: A comparison of far-right homicide incident and offender characteristics. Criminology \& Public Policy, 12(1), 65-91.

Gurr, T. R. (1970). Why men rebel. Princeton University Press.

Haidt, J., Graham, J., \& Joseph, C. (2009). Above and below left-right: Ideological narratives and moral foundations. Psychological Inquiry, 20(2-3), 110-119.

Hawthorne, G. \& Elliot, P. (2005). Imputing Cross-Sectional Missing Data: Comparison of Common Techniques. Australian and New Zealand Journal of Psychiatry. 39, 583-590.

Heidelberg Institute for International Conflict Research (2021). Conflict Barometer 2018. Retrieved from: https://hiik.de/konfliktbarometer/bisherige-ausgaben/ 
Heidelberg Institute for International Conflict Research (2021). Conflict Barometer 2019. Retrieved from: https://hiik.de/wpcontent/uploads/2020/08/ConflictBarometer_2019_4.pdf

Hertel, B. R. (1976). Minimizing error variance introduced by missing data routines in survey analysis. Sociological Methods \& Research, 4(4), 459-474.

Hirshleifer, J. (1994). The dark side of the force. Economic Inquiry, 32(1), 1-10.

Hogg, M. A. (2000). Subjective uncertainty reduction through self-categorization: A motivational theory of social identity processes. European Review of Social Psychology, 11(1), 223-255.

Hogg, M. A., \& Adelman, J. (2013). Uncertainty-identity theory: Extreme groups, radical behavior, and authoritarian leadership. Journal of Social Issues, 69(3), 436-454.

Hogg, M. A., Meehan, C., \& Farquharson, J. (2010). The solace of radicalism: Self-uncertainty and group identification in the face of threat. Journal of Experimental Social Psychology, 46(6), 1061-1066.

Hsu, M., Bhatt, M., Adolphs, R., Tranel, D., \& Camerer, C. F. (2005). Neural systems responding to degrees of uncertainty in human decision-making. Science, 310(5754), 1680-1683.

Iannaccone, L. R. (1992). Religious markets and the economics of religion. Social compass, 39(1), 123-131.

Iannaccone, L. R. (1998). Introduction to the Economics of Religion. Journal of Economic Literature, 36(3), 1465-1495.

Jäger, H., Schmidtchen, G., Süllwold, L., \& Böllinger, L. (1981). Lebenslaufanalysen (Vol. 2). Opladen: Westdeutscher Verlag. 
Janoff-Bulman, R. (1992). Shattered assumptions: Towards a new psychology of trauma. New York: Free Press.

Jasko, K., LaFree, G., \& Kruglanski, A. (2017). Quest for significance and violent extremism: The case of domestic radicalization. Political Psychology, 38(5), 815-831.

Jasko, K., Szastok, M., Grzymala-Moszczynska, J., Maj, M., \& Kruglanski, A. W. (2019). Rebel with a cause: Personal significance from political activism predicts willingness to self-sacrifice. Journal of Social Issues, 75(1), 314-349.

Jones, S. G., \& Libicki, M. C. (2008). How terrorist groups end: Lessons for countering al Qa'ida (Vol. 741). CA, Santa Monica: Rand Corporation.

Joseph, S., \& Linley, P. A. (Eds.). (2008). Trauma, recovery, and growth: Positive psychological perspectives on posttraumatic stress. NJ, Hoboken: John Wiley \& Sons.

Jost, J. T. (2017). Ideological asymmetries and the essence of political psychology. Political Psychology, 38(2), 167-208.

Jost, J., \& Hunyady, O. (2003). The psychology of system justification and the palliative function of ideology. European Review of Social Psychology, 13(1), 111-153.

Kay, A. C., \& Eibach, R. P. (2013). Compensatory control and its implications for ideological extremism. Journal of Social Issues, 69(3), 564-585.

Klor, E., \& Benmelech, E. (2016). What Explains the Flow of Foreign Fighters to ISIS?. NBER Working Paper Series. National Bureau of Economic Research.

Knight, K. (2006). Transformations of the Concept of Ideology in the Twentieth Century. American Political Science Review, 100(4), 619-626. 
Knutson, J. N. (1981). Social and psychodynamic pressures toward a negative identity: The case of an American revolutionary terrorist. Behavioral and Quantitative Perspectives on Terrorism, 105-150.

Krueger, A. B., \& Malečková, J. (2003). Education, poverty and terrorism: Is there a causal connection? Journal of Economic Perspectives, 17(4), 119-144.

Kruglanski, A. W., Gelfand, M. J., Bélanger, J. J., Sheveland, A., Hetiarachchi, M., \& Gunaratna, R. (2014). The psychology of radicalization and deradicalization: How significance quest impacts violent extremism. Political Psychology, 35, 69-93.

Kruglanski, A., Jasko, K., Webber, D., Chernikova, M., \& Molinario, E. (2018). The making of violent extremists. Review of General Psychology, 22(1), 107-120.

Leary, M. R., Twenge, J. M., \& Quinlivan, E. (2006). Interpersonal rejection as a determinant of anger and aggression. Personality and Social Psychology Review, 10(2), 111-132.

Loken, M., \& Zelenz, A. (2018). Explaining extremism: Western women in Daesh. European Journal of International Security, 3(1), 45.

Lüders, A., Jonas, E., Fritsche, I., and Agroskin, D. (2016). Between the lines of us and them: identity threat, anxious uncertainty, and reactive in-group affirmation: how can antisocial outcomes be prevented? in McKeown, S., Haji, R., \& Ferguson, N. (Eds.), Understanding Peace and Conflict through Social Identity Theory. Cham, CH: Springer

MacKenzie M.J., Baumeister R.F. (2014). Meaning in Life: Nature, Needs, and Myths. In Batthyany A., Russo-Netzer P. (Eds.), Meaning in Positive and Existential Psychology. Springer, New York, NY.

Maddux J.E. (1995). Self-Efficacy Theory. In Maddux J.E. (Ed.), Self-Efficacy, Adaptation, and Adjustment. The Plenum Series in Social/Clinical Psychology. Springer, Boston, 
Max-Neef, M. (1992). Development and human needs. Real-life economics: Understanding wealth creation, 197, 213.

McCauley, C., \& Moskalenko, S. (2011). Friction: How radicalization happens to them and us. UK: Oxford University Press.

McGregor, I., Prentice, M., \& Nash, K. (2013). Anxious uncertainty and reactive approach motivation (RAM) for religious, idealistic, and lifestyle extremes. Journal of Social Issues, 69(3), 537-563.

Mousseau, M. (2011). Urban Poverty and Support for Islamist Terror: Survey Results of Muslims in Fourteen Countries. Journal of Peace Research, 48(1): 35-47

Muller, E. N., \& Seligson, M. A. (1987). Inequality and insurgency. The American Political Science Review, 81(2), 425-451.

Østby, G. (2013). Inequality and political violence: A review of the literature. International Area Studies Review, 16(2), 206-231.

Page, B. I., \& Jacobs, L. R. (2009). Class War? What Americans Really Think About Economic Inequality. London, Chicago: University of Chicago Press.

Pervin, L. A. (1963). The need to predict and control under conditions of threat. Journal of Personality, 31(4), 570-587.

Piazza, J. A. (2011). Poverty, minority economic discrimination, and domestic terrorism. Journal of Peace Research, 48(3), 339-353.

Pinstrup-Andersen, P., \& Shimokawa, S. (2008). Do poverty and poor health and nutrition increase the risk of armed conflict onset? Food Policy, 33(6), 513-520.

Post, J. M. (1984). Notes on a psychodynamic theory of terrorist behavior. Terrorism, 7(2), 241-256. 
Post, J. M. (2007). The Mind of the Terrorist: The Psychology of Terrorism from the IRA to alQaeda. New York: Palgrave Macmillan.

Pyszczynski, T., Greenberg, J., \& Solomon, S. (1997). Why do we need what we need? A terror management perspective on the roots of human social motivation. Psychological Inquiry, 8(1), 1-20.

Rasch, W. (1979). Psychological dimensions of political terrorism in the Federal Republic of Germany. International Journal of Law and Psychiatry, 2(1), 79-85.

Robinson, L. (2009). Cultural identity and acculturation preferences among South Asian adolescents in Britain: An exploratory study. Children \& Society, 23(6), 442-454.

Rokeach, M. (1960). The open and closed mind: Investigations into the nature of belief systems and personality systems. Basic Books.

Sageman, M. (2004). Understanding terror networks. Philadelphia, Pennsylvania: University of Pennsylvania Press.

Schafer, J. L., \& Graham, J. W. (2002). Missing data: our view of the state of the art. Psychological Methods, 7(2), 147.

Shaw, E. D. (1986). Political terrorists: Dangers of diagnosis and an alternative to the psychopathology model. International Journal of Law and Psychiatry, 8(3), 359-368.

Silke, A. (2008). Holy warriors: Exploring the psychological processes of jihadi radicalization. European Journal of Criminology, 5(1), 99-123.

Simon, B., \& Hamilton, D. L. (1994). Self-stereotyping and social context: the effects of relative in-group size and in-group status. Journal of Personality and Social Psychology, 66(4), 699. 
Simon, B., Reichert, F., \& Grabow, O. (2013). When dual identity becomes a liability: Identity and political radicalism among migrants. Psychological Science, 24(3), 251-257.

Spiegler, O., Wölfer, R., \& Hewstone, M. (2019). Dual identity development and adjustment in Muslim minority adolescents. Journal of Youth and Adolescence, 48(10), 1924-1937.

Stets, J. E., \& Burke, P. J. (2000). Identity theory and social identity theory. Social Psychology Quarterly, 63(3), 224-237.

Tajfel, H., \& Turner, J. C. (1979). An integrative theory of intergroup conflict. In W. G. Austin \& S. Worchel (Eds.), The social psychology of intergroup relations (pp. 33-48). Monterey, CA: Brooks/Cole.

Tokdemir, E., \& Akcinaroglu, S. (2016). Reputation of Terror Groups Dataset: Measuring popularity of terror groups. Journal of Peace Research, 53(2), 268-277.

Turner, J. C., Hogg, M. A., Oakes, P. J., Reicher, S. D., \& Wetherell, M. S. (1987). Rediscovering the social group: A self-categorization theory. UK: Basil Blackwell.

Verkuyten, M. (2018). Religious fundamentalism and radicalization among Muslim minority youth in Europe. European Psychologist, 23(1), 21-31.

Verkuyten, M., \& Martinovic, B. (2012). Immigrants' national identification: Meanings, determinants, and consequences. Social Issues and Policy Review, 6(1), 82-112.

Verkuyten, M., \& Reijerse, A. (2008). Intergroup structure and identity management among ethnic minority and majority groups: The interactive effects of perceived stability, legitimacy, and permeability. European Journal of Social Psychology, 38(1), 106-127. 
Warburton, W. A., Williams, K. D., \& Cairns, D. R. (2006). When ostracism leads to aggression: The moderating effects of control deprivation. Journal of Experimental Social Psychology, 42, 213-220.

Webber, D., Schimel, J., Martens, A., Hayes, J., \& Faucher, E. H. (2013). Using a bug-killing paradigm to understand how social validation and invalidation affect the distress of killing. Personality and Social Psychology Bulletin, 39(4), 470-481.

Wiktorowicz, Q. (2005). Radical Islam rising: Muslim extremism in the West. Maryland: Rowman \& Littlefield Publishers.

Zellner, D., Keller, F., \& Zellner, G. E. (2004). Variable selection in logistic regression models. Communications in Statistics-Simulation and Computation, 33(3), 787-805. 